\title{
Population Structure of Blue Sheep (Pseudios nayaur) in Shimshal Valley Gilgit-Baltistan Pakistan
}

\author{
Romaan Hayat Khattak ${ }^{1,3}$, Hussain Ali ${ }^{1}$, Ejaz Ur Rehman ${ }^{1}$ and \\ Muhammad Ali Nawaz ${ }^{1,2 *}$ \\ ${ }^{1}$ Department of Animal Sciences, Faculty of Bio-Sciences, Quaid-i-Azam \\ University, Islamabad, Pakistan \\ ${ }^{2}$ Snow Leopard Trust, Pakistan Program, Islamabad, Pakistan \\ ${ }^{3}$ College of Wildlife Resources, Northeast Forestry University, Harbin, P. R. China.
}

\begin{abstract}
A B S T R A C T
Blue sheep is a key species and found in Tibetan Plateau and the bordering massif through Central Asia. In Pakistan the distribution range of species is restricted to higher altitude areas of Northern Areas including Khunjerab and Shimshal. The present study was conducted from 25 September 2014 to 23 October 2014, to estimate the population size of blue sheep in Shimshal and Socterabad Community Controlled Hunting Areas, by employing recently developed double observer-based Capture Mark Recapture method (CMR). A population of $834 \pm 356$ were estimated in Shimshal and Socterabad CCHAs, with an estimated density of $0.6 \mathrm{sheep} / \mathrm{km}^{2}$. The present study showed a female-biased sex ratio ( 80 male $/ 100$ females), probably due to ongoing trophy hunting. The young to female ratio (0.5) indicated ongoing recruitment of young. The trophy hunting operates on a sustainable use approach, as limited animals are harvested to generate economic revenues for poor mountain communities, which in turn protects the entire population and associated ecosystem from illegal massive hunting. The present study successfully tested CMR method, and produced reliable and accurate estimate of the population, which could help in determining sustainable trophy quota.
\end{abstract}

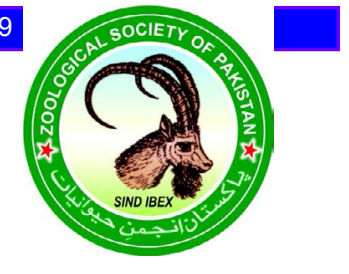

Article Information
Received 19 September 2018
Revised 22 June 2019
Accepted 02 August 2019
Available online 28 January 2020
Authors' Contribution
RHK collected data, analyzed and
wrote the manuscript. HA assisted
in data analysis. ER assisted in data
collection. MAN designed project and
redrafted the manuscript.
Key words
Blue sheep, Capture mark-recapture,
Population size, Shimshal, Trophy
hunting

\section{INTRODUCTION}

U ngulates play a key role in upholding ecosystems through influencing flora structure, plants species composition and nutrients cycling (Bagchi and Ritchie, 2010). Robust and enduring studies of population dynamics are vital for the better understanding of population ecology, wildlife management and conservation (Zhang et al., 2012). Population size can be used as best indicator for the conservation of many large herbivores species (Gaillard et al., 1998). However, conducting such large-scale and longterm surveys in the remote areas is difficult due the budget and human resource limitations (Gusset and Burgener, 2005; Singh and Gulland, 2011). For better conservation and management of wild ungulates it is necessary to study its different population parameters (Shackleton, 1997), as they are the main prey for the endangered species i.e., snow leopard (Uncia uncia) (Wegge et al., 2012). Blue sheep or bharal is a medium size wild goat (Bhatnagar, 2003),

\footnotetext{
* Corresponding author: nawazma@gmail.com 0030-9923/2020/0002-0699 \$ 9.00/0

Copyright 2020 Zoological Society of Pakistan
}

having (head to body length $=115-160 \mathrm{~cm}$, tail $=10-15$ $\mathrm{cm}$, shoulder height $=69-91 \mathrm{~cm}$ and weight $=35-75 \mathrm{~kg}$ ) (Sheikh and Molur, 2004).

The blue sheep (Pseudois nayaur) is an alpine ungulate characterized by its sociability, resides on the Tibetan Plateau and the bordering massif through Central Asia i.e. Bhutan, Nepal, China, India and Pakistan, Possibly in Tajikistan (Harris, 2003; Namgail et al., 2004). They live in groups ranging from $10-50$, but sometimes the herd size may reach up to 200 individuals (Schaller, 1977; Wegge, 1979; Wilson, 1984; Fox et al., 1986). The distribution range of the blue sheep occurs at an elevation of 4550-5480 m (Chetri and Pokhare, 2005). In Pakistan the blue sheep populations are endemic to the northern most province Gilgit-Baltistan (Roberts, 1997; Ablimit et al., 2011; Khan et al., 2012), as it is confined to the Khunjerab National Park (KNP) (Namgail et al., 2004) and neighboring parts of the upper Hunza i.e. Shimshal which perhaps represents the western most population of the sheep in the Karakorum Range (Wegge, 1988).

Blue sheep is declared as least concern globally (IUCN, 2015). One of the major threats to blue sheep populations in Pakistan is poaching (Shackleton, 2001). To minimize this threat trophy hunting has been adopted 
as a conservation tool (Lindsey et al., 2007; Nawaz et al., 2016). It allows to cull some of selected individuals from a population that can be beneficial for the rest of population to be hunted as a whole (Gunn, 2001). But without having scientific knowledge about the age of individuals in a population, the hunters target the males which in general are those facing stout sexual selection pressures (Short and Balaban, 1994). In order to make the trophy hunting a valuable tool for conservation of blue sheep and other ungulates it must be based on scientific data regarding the population size and demographic parameters of that species (Palazy et al., 2012). Another factor which is contributing towards the population downfall is the deficiency of reliable scientific data for allocation of hunting quotas (Anderson, 2001; Whitman et al., 2004; Packer et al., 2009). For estimating blue sheep population in an area, it is important to study the different parameters like group number, group size and classification by sex and age. To find the sustainability of a population it is very important to study the young to female ratio in that population (Thapa, 2013). Range number of progenies for blue sheep is $1-2$ with an average of 1.5 (WII, 2014). In case of gregarious ungulates most productive populations are considered those with a female-biased sex ratio (Caughley, 1977). Another major parameter in blue sheep population dynamics is to study the presence of trophy rams because many populations with low male-to-female ratios face the problem of lower fecundity (Solberg et al., 2002; Aryal et al., 2010b). Comparison of population size in different zones within range of that population is also very important for conservation (Aryal et al., 2010a). Fitness of a population returns from social behaviors such as group size giving many advantages like minimizing predation risks (Hamilton, 1971). Group number and group size of blue sheep increases in an area with increase in the population density (Zhang et al., 2012). Trophy hunting is basically sport hunting in which those animals are hunted having large weapons like antlers, horns or tusks. Thus, trophies are usually males, and the animals which are usually considered as trophy are ungulates species. In trophy hunting usually the hunter looking for the largest animal in a taxon or geographic area (Frisina et al., 2000). Trophy hunting is being practiced in GilgitBaltistan since 1991 (Jingfors, 2000), and the first blue sheep trophy hunt was auctioned in 2004 (Jackson, 2004). Assessment of the blue sheep population with a credible method is required for management of the declining population in Gilgit-Baltistan, and to rationalize trophy hunting quota.

\section{MATERIALS AND METHODS}

Study area

The study was conducted in Shimshal and Socterabad Community Controlled Hunting Areas (CCHAs) (Fig. 1). Both areas were notified CCHAs in 2006 under section 22 of Northern Areas Wildlife Act, 1975 (WWF, 2009). Shimshal CCHA lies in the extreme north of HunzaNagar in Shimshal valley, in Hunza-Nagar District, at an altitude of $3,100 \mathrm{~m}$ above sea level $\left(36^{\circ} 26^{\prime} 16.5^{\prime \prime} \mathrm{N}, 75^{\circ}\right.$ 19'05.8” E) (Khan et al., 2012). Along east and north, Shimshal CCHA is surrounded by the Khunjerab National Park (KNP). It is the major settlement in the District, comprising of four hamlets i.e. Khizarabad, Farmanabad, Aminabad and central Shimshal, with a population of approximately 2500 living in 300 households (Ali and Khan, 2007). Shimshal Pass $(4,735 \mathrm{~m})$ rises above the village. It lies on the watershed between the Indus River and Tarim River basins, and leads to the valley of the Shimshal Braldu River, a tributary of the Shaksgam River on the border with China. Socterabad CCHA lies in west of Shimshal CCHA, bounded by the KNP in north, at an elevation of $2,500 \mathrm{~m}\left(36^{\circ} 10^{\prime} 29.82^{\prime \prime} \mathrm{N}, 74^{\circ} 58^{\prime} 2.45^{\prime}\right.$ E). It was legally notified as CCHA in 2006 and was renotified in 2010 to adjust boundaries by Government of Gilgit-Baltistan (WWF, 2010). There are five villages in Socterabad CCHA; Shachktar, Bili, Ukulgar, Gircha and Luwarchevis, (Knudsen, 1999), which lie along the Karakoram Highway, and are socially organized in Khunjerab Villagers Organization (KVO). The KVO is mainly inhabited by Wakhi people. A conservation program with in a $30 \mathrm{~km}$ buffer zone outside the KNP border was initiated by KVO in 1996 (Khan, 1996).

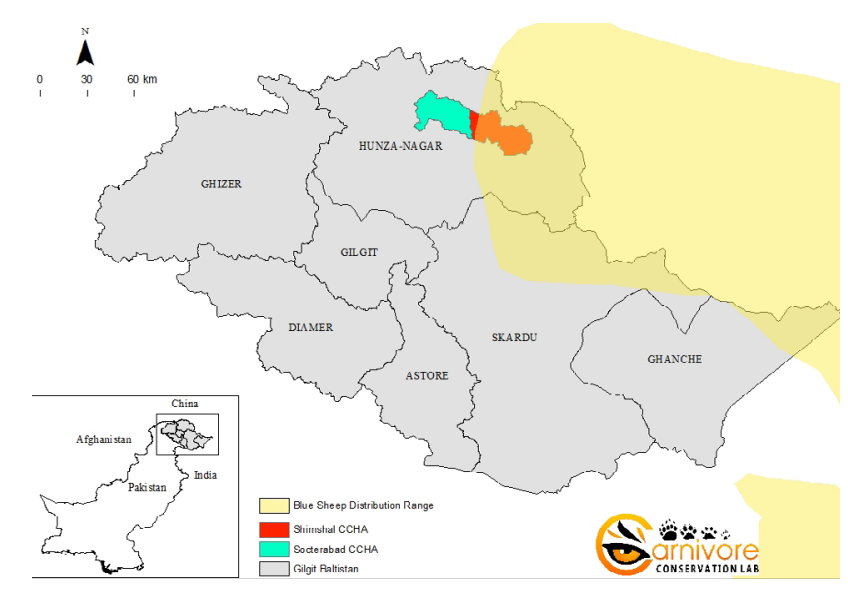

Fig. 1. Map showing distribution range of blue sheep in Pakistan including study area. 


\section{Study method}

The double observer survey method was used for estimating the blue sheep population, which is considered an effective method for estimating the population of ungulates in the mountainous areas of Central Asia and Himalayas (Suryawanshi et al., 2012; Tumursukh et al., 2015). This technique had been used for estimating abundance of Himalayan tahr (Hemitragus jemlahicus) in New Zealand (Forsyth and Hickling, 1997). This method involves two observers looking for and counting animals simultaneously. It is must to ensure that they will not cue each other if they sight animals. Both the CCHA's were divided into blocks. Depending on the area and topography, higher ridges and watersheds were considered boundaries where there is less possibility for animals to cross the block. All the blocks were scanned simultaneously. The survey was conducted from 25 September 2014 to 23 October 2014. Most sighting was done in morning (7.00 am- 10.00 am) and afternoon (3.00 pm- $6.00 \mathrm{pm})$ because blue sheep are more active during this time (Liu et al., 2005).

Twelve members participated in the survey out of which six were researchers and remaining six were wildlife watchers. The observers were divided into three teams. Each team consisted first observer and second observer. Owing to the terrain of the area both observers were temporally separated by 1 hour. Both the observers scanned these blocks and the surrounding areas moving through the predetermined trails. A spotting scope $(20 \times 60$ Swarovski) and binoculars $(10 \times 50)$ Pentax $(\mathrm{XCF})$ were used for taking observation of blue sheep. Nikon Cool Pix L10 Digital camera was used to take photographs, and data was recorded on prescribed forms. After sighting a group, it was tried best to demographically categorize the animals in female, young, class I, class II and class III males (Schaller, 1977). Males were classified on the basis of horns structural appearance. The class I young males (2-3) years old have straight emerging horns, in class II males (4-6) years old the horns bends downwards while the class III trophy males $(\geq 7)$ years have cylindrical horns which are very broad at base and curving almost horizontally outwards. Moreover, the class III males have distinct dark black shade in chest (Robert, 1997). It was difficult to distinguish the yearlings and young's so both were kept in a single category of young (less than 2 years old). To avoid double counting of groups both the observers matched their data at end of day. The groups having same number of demographic categories were considered same. In order to identify the herds on the basis of location the Global Positioning System (GPS) (GPSMAP 62s Garmin) was used to record the coordinates that were marked on the map in the field
(Namgail, 2006).

\section{Statistical analysis}

Population was estimated by using Capture MarkRecapture Method in (Specific MS Excel-2013 formats) based on the formulas (Forsyth and Hickling, 1997).

$$
\begin{gathered}
\hat{\mathrm{G}}=\frac{\left(B+S_{1}+1\right)\left(B+S_{2}+1\right)}{B+1}-1 \\
\mathrm{~N}=\hat{\mathrm{G}} \hat{\mathrm{U}} \\
\operatorname{Var}(\hat{\mathrm{G}})=\frac{S_{1} S_{2}\left(S_{1}+B+1\right)\left(S_{2}+B+1\right)}{(B+1)^{2}(B+2)}
\end{gathered}
$$

Where B is Number of groups seen by both observers, $\mathrm{S}_{1}$ is groups seen by observer first, $\mathrm{S}_{2}$ is groups seen by observer second, $\hat{G}$ is estimated number of groups, $\hat{U}$ is mean group size and $\mathrm{N}$ is estimated population.

\section{RESULTS}

\section{Population structure}

A total of 754 blue sheep were counted in 17 sightings made in Shimshal and Soctarabad Community Controlled Hunting Areas (Fig. 2). The whole area was keen-sighted by both observers with detection probability of 0.78 for observer one and 0.47 for observer two. The population was estimated at $834 \pm 356(95 \% \mathrm{CI})$ animals. The composition of recorded population included $42.7 \%$ females, $34.1 \%$ males and $23.21 \%$ young. The percentage of female was high in each CCHA with respect to male and young. Ratios for female to young, female to male and adults to young which were 1:0.5, 1:0.8 and 1:0.3 respectively. Among males the highest percentage was of class III trophy size males followed by class II and class I. The overall density for study area was 0.6 animals' $\mathrm{km}^{-2}$. The highest density was found in Shimshal CCHA (1.06 animals' $\left.\mathrm{km}^{-2}\right)$ as compared to Soctarabad CCHA (0.2 animal $\mathrm{km}^{-2}$ ).

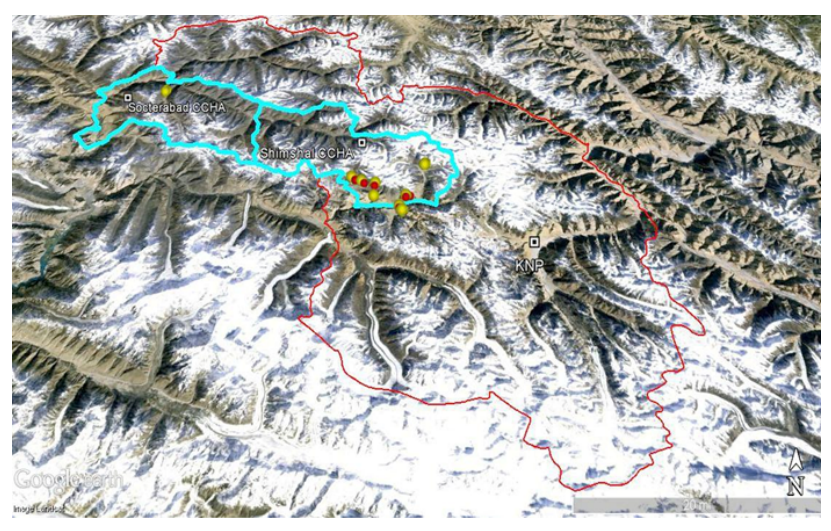

Fig. 2. Map showing locations of blue sheep sightings. Yellow and red dots indicate sightings made by observer 1 and 2, respectively. 


\section{Herd composition}

A total of 17 herds were sighted in all study blocks during this survey. Out of which 14 were mixed groups containing female, male and young while the remaining 3 were only consisting males (Fig. 3). The average herd size was (mean44.5 \pm SE 10.8). Significant variation was observed in herd sizes in both conservancies. The average herd size in Shimshal CCHA was $(46.4 \pm$ SE $12.8)$ and compared to $(34.7 \pm \mathrm{SE} 16.9)$ in Soctarabad CCHA.

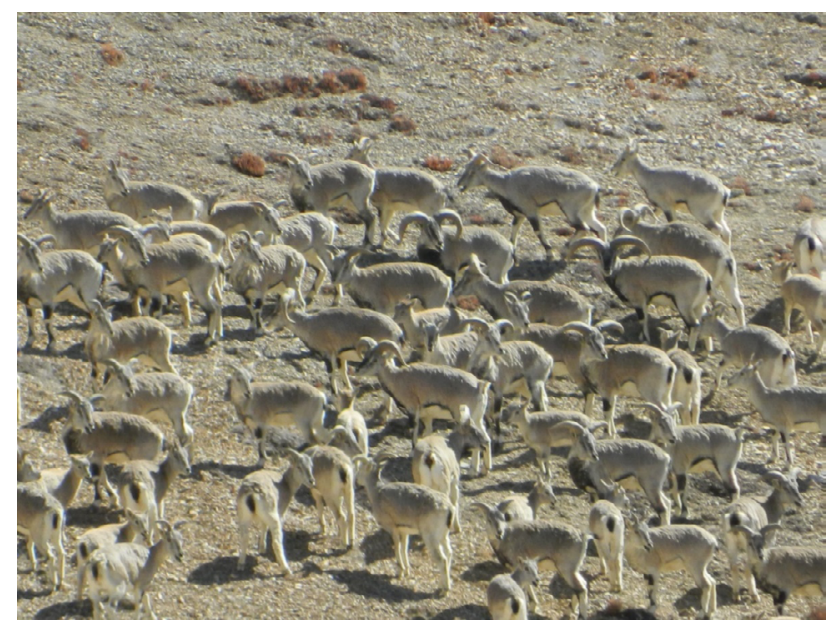

Fig. 3. Blue sheep sighted at Shimshal.

\section{DISCUSSION}

Blue sheep is a highly coveted trophy for foreigners and source of economic benefits, for impoverished remote communities of Gilgit-Baltistan since 2004 (Jackson, 2004; Khan et al., 2014). Since the inception of trophy hunting in 2004, 27 animals have been harvested. Annually 8 blue sheep could be harvested by acquiring permit at a reserve price of 8000 US $\$$ per animal (GOP, 2014), $80 \%$ of this revenue is being used for public activities and wildlife conservation activities in the custodian communities while $20 \%$ is used by Wildlife Department for Conservation of Wildlife of Gilgit-Baltistan. Quotas for trophy hunting are supposed to be based on population data (Shackleton, 2001). Therefore, proper monitoring programs are necessary to evaluate the effectiveness of conservation (Singh and Gulland, 2011).

There are several methods available for population estimation, but most of them are not suitable for rugged areas (Singh and Gulland, 2011). One of the commonly used methods for ungulates surveys in rugged areas is vantage count developed by Jackson and Hunter (1996), but owning to need of huge manpower and financial resources it is mal suggested. Suryawanshi et al. (2012) developed a more robust and rigorous method of double observer based on CMR to address the loopholes in monitoring of ungulates in rugged mountains of subcontinent. However, in this method detection probability of observer 1 appears to be higher. This phenomenon was recorded in the present study as well as in many previous studies on blue sheep and ibex in India and Mongolia (Suryawanshi et al., 2012; Tumursukh et al., 2015). The lower detection probability for observer two in these studies indicate the escaping behavior of wild mountain ungulates on sighting humans or any other threat (Tumursukh et al., 2015). According to Thompson (2004) the detection probability of observers is also affected by activity pattern of animals and other factors like climate, terrain, survey time and observer efficiency.

In Pakistan very, limited work has been done regarding census and estimation of population size of blue sheep. A total of 1,036 blue sheep were reported in a survey from Soctarabad, Khunjerab pass and Shimshal with a density of 0.523 animals per $\mathrm{km}^{2}$ (Khan et al., 2014). In a recent survey conducted in Shimshal a total of 67 blue sheep are reported with a density of 0.016 per $\mathrm{km}^{2}$ (Khan et al., 2015).

The present survey revealed an estimated population of $834( \pm 36595 \% \mathrm{CI})$ blue sheep in both CCHA's of Shimshal and Socterabad which were formerly included in KNP (Knudsen, 1999) with an estimated density of 0.6 animal's $\mathrm{km}^{-2}$. In earliest surveys, conducted by Rasool (1976, 1986), reported 35 and 170 blue sheep in 1976 and 1986 respectively from the same area. Later, Wegge (1988) reported a population of 1500 to 2000 blue sheep with an estimated density of 2-5 animals per $\mathrm{km}^{2}$ from Shimshal. This indicates that the population of blue sheep was increased after establishment of KNP in 1975. However, later Rasool (1990) reported 600 blue sheep in 1989 from the same area, indicating a drastic decrease in the population due to fatal Sarcoptes scabiei infection. Dagleish et al. (2007) confirmed that the Sarcoptes scabiei infection existed in blue sheep population of Shimshal and caused mortalities in 2000. The downfall in the blue sheep population in the area is also because of competition with the livestock for food, and excessive poaching for meat and trophies, besides disease caused mortalities (Schaller et al., 1987; Wegge, 1988; Shafique and Ali, 1998). More recently in 2005-2010, 1036 blue sheep were reported by Khan et al. (2014) from Shimshal, Socterabad and Khunjerab pass with an estimated density of ( 0.5 animals $\mathrm{km}^{-2}$ ), suggesting recovery in the population. The estimates by Khan et al. (2014) are higher than the present study because they are based on the long term and repeated field survey was conducted by Zhang et al. (2012) in Ningxia 
Helan mountains china (Zhang et al., 2012). In present study a population of 730 and 104 was estimated from Shimshal and Socterabad CCHA's, respectively, which shows higher estimate than 15 and 52 blue sheep $(0.063$ animals $\mathrm{km}^{-2}$ ) from Socterabad and Shimshal respectively reported by (Khan et al., 2015). According to Roberts (1997) blue sheep were considerably numerous in these remote areas especially of Shimshal where the hunting pressure from the locals was fairly low. The present study revealed that still a good population of blue sheep is present in the study area. Density for Shimshal estimated in the present study was (1.06 animals $\mathrm{km}^{-2)}$ which indicated that blue sheep's main stronghold is in Shimshal.

The ratio for female to young in the present study is lower than that 1:1 reported by khan et al. (2014) from the same area. Low ratio of young's in present study is due to the season of survey as it was conducted after six months (September - October) of lambing season. The earlier study by Khan et al. (2014) reported high ratio of young as it was conducted in lambing season (April - July, Roberts, 1997). Lu et al. (1994) reported same ratio of 1:0.5 for female to young in Qomolangma Nature Reserve China and declared it satisfactory recruitment in blue sheep population. The low ratio of young to females is possibly due to mass mortalities caused by harsh climate and food scarcity (Wegge, 1988, 1997). According to Dagleish et al. (2007) the young mortalities occurs because of diseases transmitted by livestock, to which the young ones are more susceptible. Festa et al. (2006) and Haller (1992) reported that stochastic killing of young ones by specialist predators also results in low ratio of young's in a population. In the present study the ratio reported for female to young was 1:0.5, which is lower than earlier reports (Khan et al., 2014). The present survey reported a female biased sex ratio like the other studies khan et al. (2014) in Shimshal, Zhang et al. (2012) in Ningxia Helan Mountains National Nature Reserve China, Aryal et al. (2010a) in Dhorpatan Hunting Reserve Nepal, Bhardwaj et al. (2010) in Gangotri National Park western Himalaya India. In case of gregarious ungulates most productive populations are considered those with a female-biased sex ratio (Caughley, 1977). According to Wegge (1979) in ungulates populations the females are usually predominant because the males are selectively hunted for trophies.

According to Aryal et al. (2010a) selective hunting of males in a population results in a low ratio of males to females. In the present survey about $45.5 \%$ of the total male population were trophy size, while Khan et al. (2014) reported $58 \%$ of males exceeding the trophy size. Low number of males in population was probably because of survey timing which was conducted in September 2014 to October 2014 before rut season. Schaller (1980) reported rut season of blue sheep from late November to January. Two isolated groups of eight and one group of five trophy size males were reported in the present study at elevation of $4351 \mathrm{~m}$ along the snow line. According to Roberts (1997) before rut season the mature male's lives in small groups of five to six individuals away from females and young mixed herds at high elevations as close as possible to the permanent snow line. Both in Shimshal and Socterabad CCHA's trophy is being practiced. In order to make trophy hunting valuable for conservation quota allocation must be made on the basis of population status. Jackson (2004) reported that one trophy quota can be set if a population containing fifty individuals with minimum four trophy size animals in two consecutive surveys. If the population reaches 150 individuals with minimum eight trophy males in two consecutive surveys, the quota could be increased to two animals.

In the present survey 17 herds were sighted with average herd size of $44.5 \pm$ SE10.8. The largest herd consisting of 150 individuals was recorded from Maidoor in Shimshal CCHA. According to Stockley (1928), Schaller (1973), Roberts (1997), blue sheep lives usually in form of small groups consisting of 10-40 individuals but sometimes may unite in large groups of up to 400 individuals. The herd size reported in this study is significantly large than other studies, Manang, Nepal (15.6 \pm SE1.3, Oli et al., 1996), Dhorpatan Hunting Reserve, Nepal ( $7 \pm$ SE5.5, Aryal et al., 2010), Ningxia Helan mountains china (8.48 \pm SE5.5, Zhang et al., 2012), and Upper Mustang, Nepal (8.4, Tapha, 2013). Both the CCHA's are low disturbed areas. According to Wilson (1981) the herd sizes are usually large in least disturbed areas.

\section{CONCLUSION AND RECOMMENDATIONS}

The population reported in this survey afford maximum eight animals for hunt. For sustainable harvest of blue sheep regular census should be made annually in future by using Double observer method based CMR. Granting hunting permits need to be conditional with a population assessment, made through a reliable estimate, and double observer based CMR is a promising technique. The IUCN should revise and update distribution range of blue sheep in Pakistan using data collected during this study and other recent studies carried out in the habitat of blue sheep. Comparing with previous studies population seems stable, trophy hunting should be continued in future.

\section{ACKNOWLEDGEMENT}

We extend sincere thanks to Snow leopard Trust (SLT) 
for their generous financial support for whole research work, which made all this possible. We are extremely thankful to Wildlife Department Gilgit-Baltistan for valuable cooperation of staff members.

Statement of conflict of interest

Authors have declared no conflict of interest

\section{REFERENCES}

Ablimit, A., Yun, W., Khan, B., Ying, H., Chen, J., Tao, S. and Zhou, J., 2011. Wild fauna along the ChinaPakistan Karakoram Highway. China J. Wildl., 32: 59-64.

Ali, A. and Khan, B., 2007. Baseline survey of Shimshal Pamir Lake: a potential high altitude wetland for transboundary cooperation between China and Pakistan. WWF Gilgit Pakistan. 32.

Anderson, D.R., 2001. The need to get the basics right in wildlife field studies., 1294-1297.

Aryal, A., Brunton, D., Ji, W. and Raubenheimer, D., 2014. Blue sheep in the Annapurna Conservation Area, Nepal: habitat use, population biomass and their contribution to the carrying capacity of snow leopards. Integr. Zool., 9: 34-45. https://doi. org/10.1111/1749-4877.12004

Aryal, A., Gastaur, S. and Menzel, S., 2010a. Population size and demographic parameters of blue sheep (Pseudois nayaur) in Dhorpatan Hunting Reserve, Nepal. Int. J. Biodiv. Conserv., 2: 51-56.

Aryal, A., Gastaur, S., Menzel, S., Chhetri, T.B. and Hopkins, J., 2010b. Estimation of blue sheep population parameters in the Dhorpatan Hunting Reserve, Nepal. Int. J. Biodiv. Conserv., 2: 051-055.

Bagchi, S.and Ritchie, M.E., 2010. Herbivore effects on above and below ground plant production and soil nitrogen availability in the trans-Himalayan shrubsteppes. Oecologia, 164: 1075-1082. https://doi. org/10.1007/s00442-010-1690-5

Begum Nilofer, A.S. and Parag, N., 2014. National studbook of blue sheep (Pseudois nayaur). Wildlife Institute of India, Dehradun and Central Zoo Authority, New Delhi. Technical Report under the project (TR-2015/00128).

Bhardwaj, M., Uniyal, V., Sanyal, A. and Sanyal, A.K., 2010. Estimating relative abundance and habitat use of Himalayan Blue Sheep Pseudois nayaur in Gangotri National Park, Western Himalaya, India. Galemys: BoletÃn informativo de la Sociedad

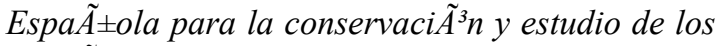
mamÃferos., 22: 545-560.

Bhatnagar, Y.V., 2003. Species of the Trans-Himalaya and other arid tracts. ENVIS Bulletin: Wildlife and Protected Areas. pp. 44-49.

Buckland, S.T., Anderson. D.R., Burnham. K.P., Laake, J.L., Borchers, D. and Thomas, L., 2001. Introduction to distance sampling estimating abundance of biological populations. Oxford University Press, New York.

Caughley, G., 1977. Analysis of vertebrate populations. John Wiley \& Sons, Chichester, United Kingdom.

Chetri, M. and Pokharel, A., 2005. Status and distribution of blue sheep, Tibetan argali and the kiang in Damodar Kunda Area, Upper Mustang, Nepal. Our Nature, 3: 56-62. https://doi.org/10.3126/ on.v3i1.335

Dagleish, M., Ali, Q., Powell, R., Butz, D. and Woodford, M., 2007. Fatal Sarcoptes scabiei infection of blue sheep (Pseudois nayaur) in Pakistan. J. Wildl. Dis., 43: 512-517. https://doi.org/10.7589/0090-355843.3 .512

Festa-Bianchet, M., Coulson, T., Gaillard, J.M., Hogg, J.T. and Pelletier, F., 2006. Stochastic predation events and population persistence in bighorn sheep. Proc. R. Soc. Lond. B: Biol. Sci., 273: 1537-1543. https://doi.org/10.1098/rspb.2006.3467

Forsyth, D.M. and Hickling, G.J. 1997. An improved technique for indexing abundance of Himalayan thar. N. Z. J. Ecol., 21: 97-101.

Fox, J., Sinha, S., Chundawat, R. and Das, P., 1986. A survey of snow leopard and associated species in the Himalaya of northwestern India. Project Completion Report,Wildlife institute of India, Dehra Dun.

Frisina, M.R., Campbell, D. and Lajia, C., 2000. Enhancing conservation of Caprinae using geographic areas to define trophy types. Presentation at the IUCN Caprinae Specialist Groups Workshop on Taxonomy and Conservation. May, 2000. Ankara, Turkey.

Gaillard, J.M., Festa-Bianchet, M. and Yoccoz, N.G., 1998. Population dynamics of large herbivores: variable recruitment with constant adult survival. Trends Ecol. Evol., 13: 58-63. https://doi. org/10.1016/S0169-5347(97)01237-8

GOP, 2014. Government of Pakistan (Wildlife Department Gilgit-Baltistan).

Gunn, A.S., 2001. Environmental ethics and trophy hunting. Ethics Environ., 6: 68-95. https://doi. org/10.2979/ETE.2001.6.1.68

Gusset, M. and Burgener, N., 2005. Estimating larger carnivore numbers from track counts and measurements. Afr. J. Ecol., 43: 320-324. https:// doi.org/10.1111/j.1365-2028.2005.00581.x 
Haller, H., 1992. Zur Á-kologie des Luchses Lynx lynx im Verlauf seiner Wiederansiedlung in den Walliser Alpen, P. Parey, Hamburg, Berlin, Germany.

Harris, R.B., 2003. Pseudois nayaur. 2006 IUCN Red List of Threatened Species.

Hamilton, W.D., 1971. Geometry for the selfish herd. J. theor. Biol., 31: 295-311. https://doi. org/10.1016/0022-5193(71)90189-5

IUCN. 2003. State of the environment and development in northern areas. Karachi, IUCN Pakistan. 38-50.

IUCN. 2015. The IUCN red list of threatened species.

Jackson, R., 2004. Pakistan community-based trophy hunting programs and their relationship to snow leopard conservation. Snow Leopard Conservancy, Sonoma, California.

Jackson, R. and Hunter, D.O., 1996. Snow leopard survey and conservation handbook. International Snow Leopard Trust, Washington and U.S. Geological Survey, Fort Collins Science Centre, Colorado, 154.

Jingfors, K., 2000. Trophy hunting updates from Pakistan. Newsl. IUCN/SSC Caprinae specialist group. 1-6.

Khan, B., Abdukadir, A., Qureshi, R. and Mustafa, G., 2011. Medicinal uses of plants by the inhabitants of Khunjerab National Park, Gilgit, Pakistan. Pak. J. Bot., 43: 2301-2310.

Khan, M.Z., Khan, B., Ahmed, E., Khan, G., Ajmal, A., Ali, R., Abbas, S., Ali, M. and Hussain, E., 2014. Abundance, distribution and conservation of key ungulate species in Hindu Kush, Karakoram and Western Himalayan (HKH) Mountain Ranges of Pakistan. Int. J. Agric. Biol., 16: 1050-1058.

Khan, B., Ablimit, A., Khan, G., Jasra, A.W., Ali, H., Ali, R., Ahmad, E. and Ismail, M., 2015. Abundance, distribution and conservation status of Siberian ibex, Marco Polo and Blue sheep in Karakoram-Pamir Mountain area. J. King Saud Univ. Sci., 28: 216-225 https://doi.org/10.1016/j. jksus.2015.02.007

Khan, B., Khan, M.Z., Ali, R., Khan, G., Ali, F. and Ali, M. 2012. Shimshal Pamir Lakes: a prospective high-altitude wetlands site for transboundary collaboration between China and Pakistan. Rec. Zool. Surv. Pak., 21: 1-9.

Khan, M.Z., Khan, B., Ahmed, E., Khan, G., Ajmal, A., Ali, R., Abbas, S., Ali, M. and Hussain, E., 2014. Abundance, distribution and conservation of key ungulate species in Hindu Kush, Karakoram and Western Himalayan (HKH) Mountain Ranges of Pakistan. Int. J. Agric. Biol., 16: 1050-1058.

Khan, Z., 1996. Call of the wild. The Herald., 27: 138-
142.

Kie, J.G., 1988. Performance in wild ungulates: measuring population density and condition of individuals. USDA Forest Service Gen. Tech. Rep. PSW-106. https://doi.org/10.2737/PSW-GTR-106

Knudsen, A. 1999. Conservation and controversy in the Karakoram: Khunjerab National Park, Pakistan. J. Polit. Ecol.: Case Stud. History Soc., 6: 1-30. https://doi.org/10.2458/v6i1.21421

Lindsey, P.A., Roulet, P.A. and Romanach, S.S., 2007. Economic and conservation significance of the trophy hunting industry in sub-Saharan Africa. Key topics boil. Conserv., 224-240. https://doi. org/10.1016/j.biocon.2006.09.005

Liu, Z., Li, X., Wang, X., Li, Z., Hu, T. and Zhai, H., 2009. Seasonal variations in group types and sizes of blue sheep (Pseudois nayaur) in the Helan Mountains, China. Acta Ecol. Sin, 29: 2782-2788.

Liu, Z., Wang, X. and Li, Z., 2007. Distribution and abundance of blue sheep in Helan Mountains, China. Chinese J. Zool. Peking., 42:1.

Liu, Z., Wang, X., Teng, L., Cui, D. and Li, X., 2008. Estimating seasonal density of blue sheep (Pseudois nayaur) in the Helan Mountain region using distance sampling methods. Ecol. Res., 23: 393400. https://doi.org/10.1007/s11284-007-0394-8

Liu, Z.S., Wang, X.M., Li, Z.G., Cui, D.Y. and Li, X.Q., 2005. Seasonal variation of diurnal activity budgets by blue sheep (Pseudois nayaur) with different agesex classes in Helan Mountain. Zool. Res., 26: 350357.

Lu, X., Jackson, R. and Wang, Z., 1994. In Fox J, Du J. Proceeding of the Seventh International Snow Leopard Symposium. International Snow Leopard Trust. Seattle. 97-103.

McCullough, B.D. and Heiser, D.A., 2008. On the accuracy of statistical procedures in Microsoft Excel 2007. Comput. Stat. Data Anal., 52: 45704578. https://doi.org/10.1016/j.csda.2008.03.004

Namgail, T., 2006. Winter Habitat partitioning between Asiatic Ibex and blue sheep in Ladakh, northern India. J. Mount. Ecol., 8: 7-13.

Namgail, T., Fox, J.L. and Bhatnagar, Y.V., 2004. Habitat segregation between sympatric Tibetan argali Ovis ammon hodgsoni and blue sheep Pseudois nayaur in the Indian Trans-Himalaya. J. Zool., 262: 57-63. https://doi.org/10.1017/S0952836903004394

Nawaz, M.A., Din, J.U., Shah, S.A. and Khan, A.A., 2016. The trophy hunting program: Enhancing snow leopard prey population through community participation. In: Snow leopards: Biodiversity of the world conservation from genes to landscapes (eds. 
D. McCarthy, D. Mallon, P.J. Nyhus). 2nd ed. 525 B Street, Suite 1800, San Diego, CA 92101-4495, USA: Elsevier., 220

Oli, M.K. and Rogers, M.E., 1996. Seasonal pattern in group size and population composition of blue sheep in Manang, Nepal. J. Wildl. Manage., 60 :797-801. https://doi.org/10.2307/3802379

Packer, C., Kosmala, M., Cooley, H.S., Brink, H., Pintea, L., Garshelis, D., Purchase, G., Strauss, M., Swanson, A., Balme, G., Hunter, L. and Nowell, K., 2009. Sport hunting, predator control and conservation of large carnivores. PLoS One, 4: 1-8. https://doi.org/10.1371/journal.pone.0005941

Palazy, L., Bonenfant, C., Gaillard, J.M. and Courchamp, F., 2012. Rarity, trophy hunting and ungulates. Anim. Conserv., 15: 4-11. https://doi.org/10.1111/j.14691795.2011.00476.x

Rasool, G., 1976. Report on the Wildlife, National Park and equivalent reserves in Northern Areas. Mimeographed report 9.

Rasool, G., 1986. Population status of blue sheep in Shimshal Valley. WWF Pakistan Newsl., 5: 1-2.

Rasool, G., 1990. Population status of wildlife in Khunjerab National Park (Pakistan). Tiger Pap., 17: 25-28.

Roberts, T.J., 1997. The mammals of Pakistan. Oxford University Press. Karachi, Pakistan, pp. 525.

Schaller, G.B., 1973. On the behaviour of Blue sheep (Pseuodois nayur). Bombay Nat. Hist. Soc., 60: 532527. https://doi.org/10.1007/BF00599439

Schaller, G.B., 1977. Mountain monarchs. Wild sheep and goats of the Himalaya, University of Chicago Press, pp. 425.

Schaller, G.B., 1980. Stones of Silence. Journeys in the Himalayas. Viking Press, New York. pp. 292.

Schaller, G.B., Hong, L., Hua, L., Junrang, R., Mingjiang, Q. and Haibin, W., 1987. Status of large mammals in the Taxkorgan Reserve, Xinjiang, China. Biol. Conserv., 42: 53-71. https://doi.org/10.1016/00063207(87)90052-8

Shackleton, D.M., 1997. Wild sheep and goats and their relatives: Status, survey and conservation action plan. IUCN/SSC Caprinae Specialist Group. IUCN, Gland, Switzerland and Cambridge, UK.

Shackleton, D.M., 2001. A review of community-based trophy hunting programs in Pakistan, IUCN, the World Conservation Union.

Shafiq, M. and Ali, A., 1998. Status of large mammal species in Khunjerab National Park. Pakistan J. For., 48: 91-96.

Sheikh, K. and Molur, S., 2004. Status and red list of Pakistan's mammals, based on conservation assessment and management plan for mammals. IUCN, Pakistan. 312.

Short, R.V. and Balaban, E., 1994. The differences between the sexes. Cambridge University Press.

Singh. N.J. and Milner-Gulland, E., 2011. Monitoring ungulates in Central Asia: current constraints and future potential. Oryx, 45: 38-49. https://doi. org/10.1017/S0030605310000839

Solberg, E.J., Loison, A., Ringsby, T.H., SÃ ther, B.E. and Heim, M., 2002. Biased adult sex ratio can affect fecundity in primiparous moose Alces alces. Wildl. Biol., 8: 117-128. https://doi.org/10.2981/ wlb.2002.016

Stockley, C. 1928. Big game hunting in the Indian empire. Constable London.

Suryawanshi, K.R., Bhatnagar, Y.V. and Mishra, C. 2012. Standardizing the double-observer survey method for estimating mountain ungulate prey of the endangered snow leopard. Oecologia, 169: 581-590. https://doi.org/10.1007/s00442-011-2237-0

Thapa, K. 2013. Blue sheep monitoring in the upper Kali Gandaki Valley. WWF Nepal, Hariyo Ban Program. 17.

Thompson, W.L., 2004. Estimating abundance of rare or elusive species. Sampling rare or elusive species: concepts, designs, and techniques for estimating population parameters, pp. 389-389.

Tumursukh, L., Suryawanshi, K.R., Mishra, C., McCarthy, T.M. and Boldgiv, B., 2015. Status of the mountain ungulate prey of the endangered snow leopard Panthera uncia in the Tost local protected area, South Gobi, Mongolia. Oryx, 1-6. https://doi. org/10.1017/S0030605314001203

Wegge, P., 1979. Aspects of population ecology of Blue sheep in Nepal. J. Asian Ecol., 1: 10-20.

Wegge, P., 1988. Assessment of Khunjerab national park and environs, Pakistan. Agricultural University of Norway, Report to IUCN, Gland. 1-25.

Wegge, P., 1997. Preliminary guidelines for sustainable use of wild caprins. and the IUCN/SSC Caprinae specialist group: wild sheep and goats and their relatives. Status survey and conservation action plan for Caprinae. Appendix I. IUCN, Gland, Switzerland and Cambridge, UK.

Wegge, P. Shrestha, R. and Flagstad, Ø., 2012. Snow leopard Panthera uncia predation on livestock and wild prey in a mountain valley in northern Nepal: implications for conservation management. Wildl. Biol.,18: 131-141. https://doi.org/10.2981/11-049

Whitman, K. Starfield, A.M., Quadling, H.S. and Packer, C., 2004. Sustainable trophy hunting of African lions. Nature, 428: 175-178. https://doi.org/10.1038/ 
nature 02395

Wildlife Institute of India (WII), 2014. National Studbook of Blue sheep (Pseudois nayaur), Wildlife Institute of India, Dehradun and Central Zoo Authority, New Delhi. Technical Report under the project, TR2015/001. pp. 28.

Wilson, P., 1981. Ecology and habitat utilisation of blue sheep Pseudois nayaur in Nepal. Biol. Conserv., 21: 55-74. https://doi.org/10.1016/00063207(81)90068-9

Wilson, P., 1984. Aspects of reproductive behaviour of bharal (Pseudois nayaur) in Nepal. Z. Saugetierk., 49: $36-42$.
WWF, 2009. Boundary delineation of Khunjerab National Park (boundary delineation and renotification of protected areas). pp. 1-47.

WWF, 2010. Use of GIS/RS for the improvement of legal notification of Khunjerab National Park a step towards better ecosystem management. pp. 1-8.

Zhang, M. Wang, X., Ding, Y., Zhang, Z., Wang, Z., Li, Z., Hu, T. and Ma, B. 2012. Population dynamics of blue sheep Pseudois nayaur in Ningxia Helan Mountain National Nature Reserve, China. Folia Zool., 61: 121-128. https://doi.org/10.25225/fozo. v61.i2.a5.2012 